\title{
Wychowanie ku „najwyższym” wartościom w dzialalności i programie ,Eleusis” w okresie niewoli narodowej
}

Przełom XIX i XX w. przyniósł w Galicji niebywały urodzaj na organizacje i ruchy młodzieżowe, które można podzielić na trzy zasadnicze kierunki: ruch sportowoturystyczno-gimnastyczny, ruch wojskowy i ruch etyczno-odrodzeniowy ${ }^{1}$. Niejednokrotnie nawiazzywały one $w$ formach swoich działań $\mathrm{i} w$ treściach do związków młodzieżowych z pierwszej polowy XIX w. ${ }^{2}$ (np.: Polskie Towarzystwo Gimnastyczne „Sokól”, Związek Młodzieży Polskiej „Zet”4 i Organizacja Młodzieży Niepodległościowej Zarzewiackiej „Zarzewie"5).

$\mathrm{Na}$ przełomie wieków szczególnym zainteresowaniem młodzieży cieszyła się ideologia narodowa. Miała ona swych piewców w osobach Stanisława Prusa-Szczepanowskiego (1846-1900), Zygmunta Balickiego (1858-1916) i Lucjana Zarzeckiego (1873-1925). $\mathrm{Na}$ uwagę zasługuje szczególnie ten pierwszy $\mathrm{z}$ racji, iż $w$ swojej ideologii potrafił połączyć pierwiastki romantyczne (jeśli chodzi o cele) z pozytywistycznymi (gdy mowa o środkach), czego nikomu wcześniej nie udało się dokonać ${ }^{6}$. Był przekonany, że Polska jest w stanie stworzyć pojęcie nowego typu człowieka-wzoru, typu będacego wyrazem potrzeb spoleczeństwa nowożytnego ${ }^{7}$, typ człowieka-obywatela, będący syntezą bohaterskich pierwiastków duszy polskiej, wyhodowanych przez dhugi okres kultury rycerskiej i uduchowionych przez poetów i filozofów romantycznych, z cechami pracownika, tak pożądanymi przez pozytywistów ${ }^{8}$. Podobnie jak polscy romantycy, Prus-Szczepanowski

${ }^{1}$ S. Grabski, Harcerstwo wśród organizacyj mlodzieży, w: Harcerstwo polskie, red. S. Sedlaczek i L. Grabowski, Warszawa 1925.

${ }^{2}$ A. Kamiński, Polskie zwiqzki mlodzieży (1804-1831), Warszawa 1963.

${ }^{3}$ M. Mirkiewicz, Towarzystwo Gimnastyczne „Sokól”. Mit a rzeczywistość, w: Galicja i jej dziedzictwo, t. 111, red. A. Meissner i J. Wyrozumski, Rzeszów 1995, s. 269-281; Leksykon harcerstwa, red. O. Fietkiewicz, Warszawa 1988, s. 433-434; K. Toporowicz, Geneza i rozwój organizacyjny Towarzystwa Gimnastycznego „Sokól” w Krakowie w latach 1885-1914, „Rocznik Naukowy Wyższej Szkoly Wychowania Fizycznego w Krakowie", 1966, T. V, s. 63-113. Por. W. Hausner, Krakowski skauting 1910-1914, Kraków 1994; W. Blażejewski, Z dziejów harcerstwa polskiego 1910-1939, Warszawa 1985, s. 20-26.

" „Zet" w walce o niepodleglośc $i$ budowę państwa. Szkice $i$ wspomnienia, red. T. W. Nowacki, Warszawa 1996; Leksykon harcerstwa..., s. 528-529; W. Blażejewski, 50 lat harcerstwa w Polsce, Dział Rękopisów Zakładu Narodowego im. Ossolińskich, rkps, sygn. 14998.

${ }^{5}$ H. Baginski, Geneza polskiego skautingu, „Harcerstwo” 1934, nr 2, s. 55-65; idem, Geneza polskiego skautingu, Warszawa 1937; idem, U podstaw organizacji wojska polskiego 1908-1914, Warszawa 1935; Leksykon harcerstwa..., s. 520.

${ }^{6}$ L. Kuberski, Stanislaw Szczepanowski 1846-1900. Przemyslowiec. Polityk. Publicysta, Opole 1997.

${ }^{7}$ B. Nawroczyński, Polska myśl pedagogiczna, Warszawa-Lwów 1938, s. 132.

${ }^{8}$ Ibidem, s. 133. Por.: F.W. Araszkiewicz, Idealy wychowawcze Drugiej Rzeczypaspolitej, Warszawa 1978, s. 32-37. 
wierzył w niezwykłą misję narodu polskiego, co silnie powiązał z religią i mistycyzmem. Był zwolennikiem odrodzenia duchowego Polaków i słusznie dziś nazywa się jego system pełnym najwyższego wysiłku i bohaterstwa ${ }^{9}$.

Ruchem, który związał poglądy S. Prusa-Szczepanowskiego z wątkiem etyczno-odrodzeniowo-abstynenckim była najbardziej kontrowersyjna, intrygująca, a jednocześnie tajemnicza organizacja tamtych czasów - „Eleusis" ${ }^{\prime 0}$. Był to ruch zainicjowany przez Wincentego Lutosławskiego (1863-1954) ${ }^{11}$, znanego filozofa, wykładowcy w Moskwie, Kazaniu, Krakowie, Genewie, Lozannie, Londynie, Dorpacie i Wilnie, członka Akademii Umiejętności, a w końcu także brata Kazimierza Lutosławskiego, legendarnego twórcy krzyża harcerskiego ${ }^{12}$.

„Eleusis" istniało w latach 1903-1920 i w poczqtkowej swej fazie było luźnym zespolem ludzi wyznajacych jego [tj. Lutosławskiego - E. G.-S.] ideologię i niepodzielne kierownictwo $^{13}$, a jego członkowie zaś rekrutowali się spośród działaczy abstynenckiego Towarzystwa „Eleuteria”"14 i Towarzystwa „Trzeźwość”, które propagowały zupełną wstrzemięźliwość od napojów ,alkoholicznych” i popierały wszelkie usiłowania mające na celu rozrywki odciagajqce od trunków gorqcych ${ }^{15}$. Wspomniane towarzystwa do celów swojej działalności zaliczały także zakładanie sanatoriów, szpitali i ambulatoriów dla alkoholików i ich leczenie. Pozytywnie także opiniowały wszelkie ustawy skierowane przeciwko pijaństwu. „Eleuteria” była również dziełem W. Lutosławskiego ${ }^{16}$.

„Eleusis", nieco tajemniczo brzmiący wyraz, to nazwa miasta w starożytnej Grecji, gdzie odbywały się misteria ludzi wolnych od nałogów i niskich namiętności (Stolica Hellenów, gdzie wybrani byli wtajemniczani i utwierdzani w posiadaniu tych prawd wiekuistych, od których postep ducha na ziemi zależy $)^{17}$. Członkowie „Eleusis” nazywali siebie elsami (wzajemnie między sobą używali zwrotów: siostro i bracie ${ }^{18}$ ), a nazwa ta

\footnotetext{
${ }^{9}$ B. Nawroczyński, Polska myśl pedagogiczna ..., s. 133.

${ }^{10}$ Materiały do historii harcerstwa - Eleusis, Archiwum ZHP, Archiwum Akt Nowych, sygn. 76/539; T. Strumiłlo, Nasze dzieje, „Harcmistrz” 1925, nr 2, s. 13.

${ }^{11}$ B. Leonhard, Harcerski slowniczek abstynencki, Kraków 1992, s. 106; Encyklopedia historii Drugiei Rzeczypospolitej, Warszawa 1999, s. 206.

${ }^{12}$ H. F. Karwowski, Ks. Pralat dr Kazimierz Lutoslawski, twórca krzyża harcerskiego, Lomża 1997.

${ }^{13}$ J. Jachowski, Harcmistrz Rzeczypospolitej (Tadeusz Strumillo 1884-1958), w: Byli wśród nas, red, F. Lenort, Poznań 1978, s. 205-218.
}

${ }^{14}$ Z. Zagórski, Eleuteria - Wyzwolenie (1902-1914), „Problemy Alkoholizmu” 1973, nr 3, s. 24-25.

${ }^{15}$ Statuty Towarzystwa „Eleuteria” i Towarzystwa „Trzeźwość”, Zespół Galicyjskiego Namiestnictwa we Lwowie, Centralne Państwowe Archiwum Historyczne Ukrainy. Oddział we Lwowie, sygn. 146/58/3061-62,
3065-66.

${ }^{16}$ Została założona w 1902 r. Poza Lwowem rozwinęła swoją dzialalność także w Krakowie, Bieczu, Przemyślu, Czerniowcach, Stanislawowie, Tarnopolu, Kosowie i Jarosławiu. Członkowie Eleuterii zorganizowali polskie kongresy przeciwalkoholowe w 1904, 1905 i 1912 r., akcję oświatowa i wydawnicza, akcje zamykania szynków w niedziele i święta, popierania w wyborach do samorządu tylko takich posłów i radnych, którzy manifestowali swoją abstynencję. Eleuteria skupiła w swoich szeregach wiele wybitnych postaci: Dybowskiego, Bujwida, Zapolska, Konopnicka, Sienkiewicza, Małkowskich, Strumiłłe, Daszyń-
ską-Golińska. Patrz: B. Leonhard, op.cit.

${ }^{17}$ Leksykon harcerstwa, s. 87, B. Leonhard, op.cit., s. 51-52.

${ }^{18}$ Ze względów konspiracyjnych jednak używano pseudonimów, często nawiązujących do nazw związanych z przyroda. 
pochodziła od pierwszych liter greckiego zdania: Eleutheroi laon sotheres, co znaczy: ,wolni wybawcami ludów"19. Wielu elsów, wychowanych w kulcie romantyzmu, rozumiało to w sposób zbyt dosłowny.

Członkowie „Eleusis” ślubowali dożywotnią poczwórną wstrzemieźliwość: od alkoholu, tytoniu, kart i rozpusty ${ }^{20}$. Do przestrzegania takiej abstynencji zobowiazywały elsów: słowo honoru, przysięga kościelna i solenny ślub. Sens takich ślubów upatrywano w potrzebie przygotowania młodych Polaków do walki o niepodległość przez kształcenie ich moralności, odrzucano bowiem w „Eleusis” metodę przemocy i walki zbrojnej. Ponadto motywacja młodych ludzi do zachowania aktywności abstynenckiej opierała się na dwóch filarach: walki $\mathrm{z}$ tendencją zaborców do rozpijania polskiego społeczeństwa oraz walki o biologiczną pełnowartościowość Polaków, ich szczęście rodzinne i pomyślność zawodową. Istotny był także motyw widocznej pracy nad soba, co pozytywnie oddziaływać mogło na otoczenie młodego człowieka, który jawnie mógł manifestować swoją abstynen$\mathrm{cję}^{21}$. Pomagać mu w tym miały ćwiczenia jogów indyjskich, praktyki katolickie, pilna lektura pism mesjanistów polskich i praca oświatowa wśród ludu. Członków obowiazywał ścisły regulamin, zwłaszcza jeśli chodzi regularne opłacanie składek i o obecność na zebraniach (np. Iwowscy elsowie zbierali się w każdą niedzielę, wczesnym rankiem, bywało, że nawet o godzinie 4 rano, w domu p. Krasuskiej, nieopodal cerkwi św. Jura).

Towarzystwo utrzymywało się ze składek swoich członków, z wykładów publicznych, z wydawnictw i z ofiar dobroczyńców. W Statucie „Eleusis” młodzież kształcąca się prywatnie, miała zagwarantowaną pomoc w postaci specjalnych pensjonatów, wykładów, bibliotek ${ }^{22}$. Pośród członków istniała hierarchia. Dzielono ich bowiem na: próbnych, zwyczajnych, wolnych i honorowych. Członkiem próbnym mógł zostać każdy zwyczajny i nadzwyczajny słuchacz Uniwersytetu (Jagiellońskiego w przypadku Krakowa), należący do Kościoła katolickiego. Swój status mógł zmienić po upływie roku próbnego, lub wcześniej, jeśli władze wyraziły na to zgodę. Członkowie wolni natomiast wybierani byli jednomyślnie spośród wszystkich członków zwyczajnych za specjalne zasługi. Członków honorowych zaś miano, w świetle Statutu, wskazywać na wniosek władz Towarzystwa z grona profesorskiego. Władzami „Eleusis” były: Wydział, składający się z sekretarza, skarbnika, ich zastępców i gospodarza, Zebranie wszystkich wolnych członków, Zebranie członków zwyczajnych i próbnych i Kurator Towarzystwa. Obsadę ostatniego miał zagwarantowany Wydział Teologiczny ${ }^{23}$.

„Eleusis” miało charakter organizacji ściśle katolickiej - rodzaj świeckiego zakonu. Nie uzyskał on jednak nigdy oficjalnego błogosławieństwa Kościoła katolickiego. Wręcz

\footnotetext{
${ }^{19}$ Przeciwnicy Lutosławskiego podawali nieco inna, $w$ ich rozumieniu bluźniercza, etymologię tego słowa. Els bowiem był to także skrót trzech wyrazów hebrajskich: Eli lamma sabachtani, wypowiedzianych przez Chrystusa na krzyżu. Znaczyć to by miało, że elsy powstały w odpowiedzi na to wolanie...

${ }^{20}$ Statut Koła Akademickiego Towarzystwa „Eleusis”, Zespół Galicyjskiego Namiestnictwa..., sygn. 146/58/3065, B. Leonhard, U źródel profilaktyki przeciwalkoholowej w harcerstwie, „Problemy Alkoholizmu" 1970 , nr 10, s. 22-24.

${ }^{21}$ A. Kamiński, Andrzej Matkowski, Warszawa 1979, s. 13.

${ }^{22}$ Statut Koła Akademickiego Towarzystwa „Eleusis”....

${ }^{23}$ Dokładny opis kształtowania się struktury organizacyjnej i rozwoju sieci terytorialnej kół zawiera praca T. Podgórskiej, Stowarzyszenie Patriotyczno-Religijne Eleusis w latach 1902-1914, Lublin 1999, s. 53-102.
} 
przeciwnie, często Lutosławskiego i jego „dzieci” posądzano o herezję i obłudę ${ }^{24}$. Wykorzystywano w tym celu fakt usunięcia „Lutosa” (jak nieoficjalnie nazywali elsowie Lutosławskiego) ze stanowiska docenta Uniwersytetu Jagiellońskiego ${ }^{25}$. Środowiska kościelne obawiały się ponadto chaosu i zamętu, jaki hasła elsów i ich „Ojca-Inicjatora” mogą wnieść w sposób myślenia polskiego społeczeństwa ${ }^{26}$. Niepokojące było także to, że Lutosławski wielokrotnie odwoływał się do tradycji i zwyczajów starożytnych, co przez jego przeciwników odbierane było jako zwykły przejaw pogaństwa i zapatrzenia we wzory masońskie. Nie przekonywały ludzi Kościoła nawet śluby wstrzemięźliwości... Tym bardziej, że rozumienie np. abstynencji seksualnej Lutosławskiego rozmijało się z oficjalnym stanowiskiem Kościoła. Potępiał on także zasadę koedukacyjności, lansowaną w „Eleusis”.

„Eleusis" redagowało swoje własne, wspólnie przygotowywane, wydawnictwa. Najważniejszym z nich były kolejne tomy „Eleusis”. Ukazało się sześć numerów, siódmy bowiem, pisany już w odrodzonej Rzeczypospolitej, zawierający wspomnienia po zmarłych elsach, częściowo napisany przez Tadeusza Strumiłłę, nie został wydany z powodu wybuchu II wojny światowej. Podobny los spotkał także „Brewiarz eleuzyński”, opracowany przez elsów na podstawie Pisma świętego, pism Ojców Kościoła, żywotów świętych, dzieł wieszczów, Norwida, Towiańskiego. Ten tekst także został pogrzebany przez działania wojenne ${ }^{27}$.

Elsowie dużą rolę przypisywali oddziaływaniu na Polaków ich wieszczów narodowych, filozofii narodowej (która zerwać miala wszelkie związki z zarazq pozytywistycznq), autorstwa samego Lutosławskiego ${ }^{28}$, gdzie kluczowym pojęciem było pojęcie narodu $^{29}$. Jego system pojmował jednakże świadomość narodową nie jako jednolitość rasy, ale ducha, bo $z$ niego jedynie wynikać mogą wspólne dążenia narodowe. A świadomość narodowa rodzi się wskutek wspólnych przeżyć całej grupy, pogłębia ją także twórczość artystyczna i literacka. Wzorcowym przykładem narodu dla Lutosławskiego był naród polski, na powstanie którego złożyły się doświadczenia i historia wielu plemion, grup etnicznych i ludów. „Mistrz Wincenty” był jednak przeciwnikiem pychy rasowej i uważał, że unie narodów (zapoczątkowane przez Polskę w XIV w.), zwłaszcza tych mniejszych, stają się ich koniecznością. Małe państwa bowiem, nie są w stanie zapewnić sobie niezależności inaczej, jak przez fakt łączenia się i tworzenia wielkiego mocarstwa.

Ideologia narodowa w wydaniu eleuzyjskim zbliżona była bardzo do polskiego mesjanizmu, jej popularność zaś w początkach XX w. była wynikiem odrodzenia się w tym

\footnotetext{
${ }^{24}$ Patrz np.: ks. K. Majewski, Czy Eleusis pana Lutoslawskiego jest katolickim czy masoniskim zakonem?, Częstochowa 1910.

25 Senat Akademicki wystosował nawet pismo do c. k. Naczelnictwa, w którym krytykuje statut Kola Akademickiego Towarzystwa Eleusis (krótko jest on omówiony w tekście), który miał zatwierdzić. Senat prosi w tym piśmie o nieprzyjęcie owego statutu, bo pozostaje on pod kierunkiem dra Lutosławskiego, a jest on niezdrowy bałamutny i szkodliwy dla młodzieży, patrz: Statut Koła Akademickiego Towarzystwa Eleu-
sis, Zespół Galicyjskiego Namiestnictwa....

${ }^{26}$ Lutosławskiego porównywano zatem do największych „wichrzycieli” XIX w., w tym także do Andrzeja Towiańskiego.

${ }^{27}$ J. Jachowski, op.cit., s. 208.

${ }^{28}$ Lutosławski w 1902 roku założyl także Seminarium Wychowania Narodowego.

${ }^{29}$ W. Lutosławski, Filozofja narodowa, "Przegląd Filozoficzny", 1934, R. XXXVII; B. Leonhard, op.cit.,
106.
} 
okresie haseł romantycznych w postaci ideologii neoromantycznej. Ruch elsów był zjawiskiem charakterystycznym dla przełomu wieków, świadczył o zmianie nastrojów wśród młodzieży polskiej, której nie odpowiadał już styl życia zaproponowany przez ducha Młodej Polski. Sam Lutosławski znany był ze swojego wrogiego stosunku wobec ,przybyszewszczyzny”.

System Lutosławskiego B. Nawroczyński scharakteryzował jako pluralistyczny spirytualizm, polaczony $z$ wiarq $w$ preegzystencje dusz indywidualnych $i$ metempsychozę. Obok nieśmiertelnych jaźni indywidualnych istnieja jaźnie narodowe ${ }^{30}$. Doskonalenie się zaś jaźni jako takiej polega na zdobywaniu coraz pełniejszej świadomości swej odrębności duchowej i swego powołania. Według Lutosławskiego szczególną funkcję do spełnienia ma właśnie naród polski - zbawiać innych. Gdy Polacy spełnią należycie swoje zadanie, reszta narodów zorganizuje całą ludzkość na zasadach miłości i na tym będzie polegało urzeczywistnianie Królestwa Bożego na ziemi.

Także Władysław Tatarkiewicz zaliczył Lutosławskiego, wraz ze Stanisławem Brzozowskim i Edwardem Abramowskim, do nurtu filozoficznego zwanego spirytualizmem. Zaznaczył jednak przy tym odmienność metafizyki tego pierwszego, bo glosiła nie tylko samoistność duchów, ale też wielokrotność ich wcieleń, palingenezę. Lqczyla się z mistyczna teoriq poznania. I kladla szczególny nacisk na myśl, że najwyższq realnościa metafizycznq jest naród, a najwyższym źródlem poznania świadomość narodowa ${ }^{3 !}$. Lutosławski uważał się za ucznia Platona, ale tego twórcę filozofii idealistycznej interpretował, jak wszystko inne, po swojemu - spirytualistycznie.

Filozofia W. Lutosławskiego nigdy nie zyskała w Polsce szerszego uznania; w czasie swego największego rozkwitu w 1907 r. „Eleusis” liczyło kilkaset członków we wszystkich zaborach. Podatni na wpływy eleuzyjskie byli przede wszystkim studenci i robotnicy (wśród nich akcję oświatową prowadzono na Górnym Śląsku, w Nadrenii i w Westfalii ${ }^{32}$ ). Trudno jest jednak nie zauważyć, iż Lutosławski był postacią nietuzinkową. Wspomnienie o nim, bardzo ciepłe, zachowała Olga Małkowska, twórczyni żeńskiego skautingu dla dziewcząt. Powiedziała o nim bowiem znakomity filozof, przemadry, przedobry czlowiek, chociaż straszny dziwak. Pamiętam, jak kiedyś, nie mogqc zapewnić sali wykładowej, zgromadzil nas na którejś z lwowskich ulic, sam wlazl na latarnię i mial do nas dluższa przemowe. Poczciwy stary Lutos... ${ }^{33}$.

W roku 1912 elsowie odsunęli się od swego Ojca-Inicjatora, głównie za sprawą licznych ekscesów i ekstrawagancji „,mistrza Wincentego" ${ }^{34}$, albo jak stwierdził els Stanisław

\footnotetext{
${ }^{30}$ B. Nawroczyński, op.cit., s. 154.

${ }^{31}$ W. Tatarkiewicz, Historia filozofii, Warszawa 1983, t. III, s. 359

${ }^{32}$ Elsów spotkały za to represje ze strony władz pruskich w postaci tzw. procesów abstynenckich w roku 1904 i 1905. Patrz: B. Nawroczyński, op.cit., s. 154.

${ }^{33}$ G. Bytnar, Piękna mlodość. Rozmowa z Olgq Drahonowskq-Malkowskq, „Tygodnik Powszechny” 1978 , nr 11.

${ }^{34}$ Podobnie postąpiły już wcześniej władze Uniwersytetu Jagiellońskiego, odbierając Lutosławskiemu prawo do wykładów na w/w uczelni. Po tej decyzji zaczął więc tworzyć razem z gromadką gorących wielbicieli właśnie „Eleusis”. Ekstrawagancją ze strony Lutosławskiego było także opublikowanie w roku 1933 zaskakującej autobiografii Jeden latwy żywot. Zarzucano Lutosławskiemu także sprzeniewierzenie się ideałom eleuzyńskim, ponieważ porzucił swoją pierwszą żonę, poetkę Zofię Casanovę (ożenił się $z$ nią $w$ marcu 1887 r.), z powodu braku miłości, jak sam twierdził. Ożenił się „Lutos” także ponownie z jedną z elsek, Wandą Peszyńską.
} 
Pigoń, wskutek autokratycznego nastawienia i niekonsekwencji założyciela. Wielu elsów miało Lutosławskiemu po prostu za złe także jego częstą nieobecność i wyjazdy. W miejsce „Eleusis” utworzono, po naradach w Kosowie (1910) i Żółkowie (1912), Filarecki Związek Elsów. ${ }^{35} \mathrm{Na}$ sejmie w Kosowie Lutosławski był obecny, ale nieoficjalnie. Udziału w zebraniach nie brał, jedynie zapraszał na dyskusje chętnych do tego elsów. Zjawił się także w Żółkowie, gdzie zaatakował najaktywniejszych działaczy eleuzyjskich, zarzucił im zdradę, przywłaszczenie wodzostwa wśród elsów, zmianę celów działania. Trudno mu było się pogodzić z faktem usamodzielniania się „Eleusis”. W jego miejsce zatem utworzył „Zakon Kowali”, gdzie naczelnymi hasłami były: dzielność, sprawność i karnośćc ${ }^{36}$.

Mimo że stosunki Lutosławskiego z elsami pogarszały się, to tematyka wykładów na obu sejmach wskazywała jasno, że „Mistrz Wincenty” nadal pozostał „ojcem duchowym" dla wielu sióstr i braci. W Kosowie T. Strumiłło wypowiedział się w imieniu całego „Eleusis" na temat stosunku do swego inicjatora i jego obecnej roli w związku. Stwierdził wówczas, że System jego [tj. Lutosławskiego - E. G.-S.] filozofii nazywany eleuteryzmem, jest uwazany za tak dalece przeciwny nauce katolickiej, że wobec przypisywania nam bezwzględnej uleglości wptywom Lutoslawskiego - doczekaliśmy się ze strony duchowienstwa ostrych napaści i zarzutów, jakbyśmy pod plaszczykiem religijności przemycali poglady sprzeczne z naukq Kościola - wręcz heretyckie. To podejrzenie odeprzeć musimy jak najenergiczniej [...]. Zarzuty owe przede wszystkim wyróść moghy na gruncie ignorancji, niezrozumienia rozwoju jego poglqdów, na przypuszczeniu, co gorsze, zlej woli. Bo oto krańcowego indywidualizmu negującego Boga, Stwórce, Wszechmocnego Ojca wszystkich jaźni - wyrzekt się sam Lutoslawski, jeszcze zanim Eleusis powstalo. Natomiast eleuteryzm, pogodzony z ideq Boga chrześcijańskiego, odpowiadajacy postępowi filozoficznej myśli europejskiej $i$ właściwy Wieszczom narodowym, acz przez nikogo jeszcze systematycznie nieprzedstawiony, nie ma w sobie nic przeciwnego nauce katolickiej. Inna rzecz, że Lutoslawski tego pogodzenia dotqd w calości nie przeprowadzil [...]. Że jednak z tego powstaje zarzut przeciwko Eleusis, to wskazuje na zasadnicze niezrozumienie stosunku naszego do Wincentego Lutosławskiego. [...] Nie jesteśmy jako organizacja $w \dot{z} a d n e j$ od niego zależności, nie jest on ani naszym kierownikiem, ani wodzem, ani nawet czlonkiem Eleusis. [...] On nam wskazal źródta, z których sam czerpal. W filozoficznym postępie ludzkości, a charakterze narodowym ducha polskiego, dochodzqcego $w$ Wieszczach do szczytu, tkwi przyczyna naszych podobienstw ${ }^{37}$.

Uczniami Lutosławskiego było jednak wielu wybitnych dla polskiej nauki i kultury ludzi: wspomniani już S. Pigoń ${ }^{38}$, T. Strumiłło ${ }^{39}$, Andrzej i Olga Małkowscy, Józef Ko-

\footnotetext{
${ }^{35}$ Materiały do historii harcerstwa - Eleusis...; Por. T. Strumiłło, Nasze dzieje, „Harcmistrz” 1926 , nr 1-2, s. 11 .

${ }^{36}$ Organizacja ta okazala się efemeryda, większość kowali po krótkim czasie powróciło na lono Filareckiego Związku Elsów. Patrz: J. Jachowski, op.cit., s. 214.

${ }^{37}$ Ibidem.

${ }^{38} \mathrm{O}$ swoich doświadczeniach eleuzyjskich z lat młodości pisał w swojej autobiografii, Z Komborni $w$ swiat, wydanej w Krakowie w roku 1957.

${ }^{39}$ J. Jachowski, op.cit., s. 205.
} 
strzewski $^{40}$, Adam Wodziczko, Ignacy Kozielewski, Stanisław Cywiński, Maria Jarecka, siostra S. Prusa-Szczepanowskiego. Wielu elsów wstapiło później w szeregi polskich skautów i to właśnie dzięki duchowi eleuzyjskiemu polskie harcerstwo zawdzięcza w Prawie Harcerskim punkt o abstynencji alkoholowej i tytoniowej ${ }^{41}$. Znaczenie zaś i wpływ harcerstwa na polską młodzież są dziś bezdyskusyjne.

\footnotetext{
${ }^{40}$ Swoje wspomnienia spisal także J. Kostrzewski. Patrz: tenże, $Z$ mego życia. Pamiętnik, Wrocław 1970 Patrz także: A. Marciniak, Józef Wladyslaw Kostrzewski, w: Poczet wielkopolskich czlonków Polskiej Akademii Nauk, Poznań 2000.

${ }^{41}$ Patrz: E. Głowacka-Sobiech, Twórcy polskiego skautingu - Olga i Andrzej Malkowscy, Poznań 2003.
} 